\title{
УДК: 327:94
}

http://doi.org/10.17721/2521-1706.2016.02.236-244

Сергій Толстов, кандидат історичних наук, доцент, Державна установа «Інститут всесвітньої історії НАН України»

\section{СТРУКТУРНІ ТА ПОЛІТИЧНІ ОЗНАКИ БАГАТОПОЛЯРНОСТІ}

Анотація. У статті розглянуто основні тенденції становлення та розвитку багатополюсної міжнародної системи міжнародних відносин. У ній зосереджено увагу на аналізі, загальній класифікації форм системної організащії міжнародних відносин, яка трунтується на співвідноченні матеріальних чинників у поєднанні з оцінкою позищіонування провідних держав, міждержавних утворень на міжнародній арені. Показано як особливості, індивідуальність, так $і$ характерні риси, закономірності втілення міжнародних програм в окремих політичних обставинах у ключові, визначальні періоди світової історії. Актуальність роботи виходить з усвідомлення подій останніх років, процесу політичних змін в міжнародних відносинах, світовій політиці які набули інтенсивних, несподіваних рис.

Автор також намагається продемонструвати, щзо в перспективі полічентризм може набувати різних форм та конфігурацій, очінка перших проявів багатополярності дозволяє констатувати посилення нестабільності та конфронтації в міжнародних відносинах за сучасних умов формування нового світового порядку. Розвиток міжнародних прочесів в зазначеному напрямку був обумовлений агресивними та свідомими діями Росії, спрямованими на руйнування попереднього міжнародного порядку, спроби переглянути встановлені десятиліттями загальновизнані правила та норми у світовому співтоваристві.

Ключові слова: багатополярність, структура, ичивілізація, баланс сил, стабільність, конфронтація.

В якості специфічного підрозділу наукових знань про міжнародні відносини аналіз та моделювання міжнародних систем належать до найбільш дискусійних та суперечливих напрямів. В загальному вигляді класифікація форм системної організації міжнародних відносин грунтується на співвідношенні матеріальних чинників у поєднанні з оцінкою позиціонування провідних держав на міжнародній арені. На підставі дескриптивних показників, які піддаються матеріальній оцінці, визначенню й співставленню, міжнародні системи розрізняються за ознаками розподілу влади, полярності та стабільності. До основних типів міжнародних систем належать багатополярна, біполярна та однополярна, які в свою чергу можуть відрізнятися за показниками рівноваги чи нерівноваги. На основі досвіду емпіричних спостережень вважається, що розподіл владних можливостей у міжнародній системі визначають кількість великих держав і характер відносин між ними, від чого залежить полярність міжнародної системи. Якщо великих держав більше двох, міжнародна система тяжіє до поліцентризму.

Із точки зору історичного досвіду ідеальних стандартів міжнародної системи не існує й напевно існувати не може. Форми міжнародної організації та взаємодії змінюються в залежності від співвідношення сил та характеру відносин між державно організованими суспільними утвореннями. В грунтовній праці С. Кауфмана, Р. Літтла та У. Уолфорта «Баланс сил у світовій історії» (2007р.) 
знаходимо аналіз співвідношення між періодами відносної рівноваги та описання прикладів домінування окремих держав, коли баланс сил був порушений упродовж тривалого часу [10]. За оцінками авторів цього дослідження, на ситуації, в яких спостерігалося втілення принципів класичного балансу сил, припадала приблизно половина історичного часу. Це не дозволяе вважати баланс сил за «трансісторичний факт», хоча й не спростовує статистичної більшості випадків різних форм балансування порівняно з іншими формами безпекової поведінки у владно-силовому контексті. При цьому в історії спостерігалося відносно небагато випадків «абсолютної» гегемонії тієї чи іншої держави, на кшталт Римської імперії за часів античності або домінування США наприкінці XX - початку XXI ст.

Як свідчать події останніх років, процес політичних змін в міжнародних відносинах значно прискорився. Перегляд політичного ландшафту випереджає зміни в економічному балансі та спростовує гіпотезу про обов'язковість повної взаємозалежності між економічним потенціалом, станом воєнної сили та політичною активністю тих чи інших країн.

Мета статті полягає в спробі попереднього визначення характеристик та ймовірних ознак багатополярної (поліцентричної) міжнародної системи, процес становлення якої розпочався на тлі глобальної економічної кризи з 2008 р.

У політичних теоріях реалістичного спрямування оцінка спроможності тих чи інших суб'єктів впливати на процеси і тенденції міжнародної взаємодії визначається термінами влади, які оцінюються за трьома основними критеріями. До них належать: наявність ресурсів і факторів, що забезпечують спроможність впливу, включаючи силові та економічні; здатність контролювати інших акторів; наявність структурних елементів влади та впливу. В останньому випадку мається на увазі розподіл можливостей, що дозволяють застосовувати примусові дії та обмеження, спроможність впливати на міжнародне право, міжнародні режими та загалом установлювати «правила гри», яким мають слідувати інші держави та міжнародні суб'єкти [9, р. 25].

У найпростішому вигляді спосіб зміни полярності міжнародної системи визначається нерівномірністю розвитку та змінами в співвідношенні потенціалів провідних акторів. Втім, виглядає доцільним простежити, як застосування цих критеріїв позначається на процесі змін у міжнародних відносинах у практичному сенсі.

Упродовж XX ст. міжнародна система зазнала декілька фаз еволюційної трансформації. На початку XX ст. мав місце перехід від європейської багатополярної системи балансу сил XIX ст. до формування потужних коаліцій, які стали головними учасниками першої світової війни 3 подальшим поверненням до хиткого поліцентризму міжвоєнного періоду 1920-1930-х рр. Злам європейської міжнародної системи в роки другої світової війни завершився встановленням біполярної моделі, в якій США та СРСР відігравали роль гегемонічних держав у світі, частково поділеному на зони преференційного впливу.

У своїй книзі «Піднесення і занепад великих держав» (1987 р.) професор Єльського університету П. Кеннеді передбачав, що продовж 20-30 років динаміка економічного розвитку спричинить зміни в балансі воєнної сили, що призведе до виникнення мультиполярного світу [11]. Такі очкування висловлювали й інші дослідники, які вважали, що закінчення «холодної війни» та силового протистояння між США та СРСР спричинить зміну правил гри та конкуренції на 
міжнародній арені. За спостереженням П. Кеннеді, вже наприкінці XX ст. простежувалися симптоми потенційного скорочення американського впливу. Ознаками цього вважалися відносне зменшення частки ВВП США в світовій економіці та «імперське перенапруження», спричинене контролем глобальних комунікацій i військовими витратами. Західні дослідники попереджали про можливість змін у балансі потенціалів США та низки регіональних держав, насамперед в Азії (Китай, Іран, Індія) [8, р. 20-21].

Розпад СРСР змінив розстановку сил у глобальній міжнародній системі та вектор іiі подальшої еволюції. Збереження існуючої системи політичних i військових союзів дозволило уникнути суттєвих політичних розбіжностей між основними центрами сили західного світу, а розширення західного капіталізму в формі глобалізації сприяло ресурсній підтримці провідних західних економік та політичному домінуванню США в системі міжнародних відносин. Подальші зміни зачіпали насамперед корекцію співвідношення потенціалів у межах «великої трійки» західного світу, яку складали США, ЄС та Японія.

Чергова фаза глобальних соціально-економічних диспропорцій була пов'язана 3 початком фінансово-економічної кризи 2008 р., яка, за деякими прогнозами, триватиме ледь не до початку чи навіть середини 2020-х рр. Фінансова криза та нестабільність економік країн євроатлантичної спільноти стали імпульсом, що сприяв прискоренню переходу до нової багатополюсної (поліцентричної) моделі міжнародних відносин.

На відміну від європейської поліцентричної системи XIX ст. нова багатополярна конфігурація має глобальний характер і не обмежується суто європейськими рамками. Як відзначав С. Хантінгтон, після «холодної війни» створився «багатополюсний, поліцивілізаційний світ», якому не властивий всеохоплюючий розкол в усіх сферах, який спостерігався в попередні роки $[7$, с. 384]. Проте відсутність поляризованої політико-ідеологічної матриці не означає усунення принципових протиріч, які обертаються конфліктом між різними способами політичної організації державних інститутів та формами досягнення політичних та економічних інтересів. До того ж, на думку С. Хантінгтона, початок переходу від європейської міжнародної системи до «постєвропейської мультицивілізаційної» почався з приходом марксистів до влади в Росії (19171918 рр.), Китаї та В’єтнамі (1945-1949рр.). За його ж оцінкою, наприкінці ХХ ст. обидва компоненти цивілізаційного Заходу в Північній Америці та Західній Європі, еволюціонували в бік «універсальної держави». Поєднані складною мережею формальних і неформальних інституціональних зв'язків, обидві частини західного цивілізаційного комплексу створюють специфічну систему федерацій, конфедерацій, міжнародних режимів та організацій [7, с. 71]. Наявність привілейованих зв'язків та забезпечення регулярного політичного діалогу дозволяє розглядати США і $Є С$ як взаємопов'язані елементи, що створюють спільний, хоча й децентралізований полюс сили. 3 точки зору цивілізаційної теорії С. Хантінгтона, «породжене Заходом внутрішньоцивілізаційне зіткнення політичних ідей», яке тривалий час слугувало ідейною формою внутрішньоєвропейських конфліктів, «витісняється міжцивілізаційним зіткненням культур і релігій» [7, с. 71]. 3 другого боку, поліцентризм у міжнародних відносинах означає розосередження влади та скорочення можливостей гегемонії одного з багатьох центрів сили, які тією чи 
іншою мірою вступають в опозицію до домінуючих держав та створених ними об'єднань.

За суто матеріальними ознаками сучасна поліцентрична система, що формується, в якості основних або вагомих елементів включає переважну більшість держав, які беруть участь у форматі діалогу «Великої двадцятки» (G20), а також ряд інших країн на кшталт Ірану, Сирії чи Північної Кореї, які відіграють значну роль у важливих регіонах, впливають на баланс сил чи виступають у якості джерел напруженості.

Водночас у межах постпозитивістського підходу теорія вважається самодостатнім дискурсом, який не тільки відтворює на суб'єктивному рівні об'єктивний стан справ, але й конструює певну реальність. В такому ракурсі свідоме прагнення урядів низки країн до створення багатополярної міжнародної системи, позначене в урядових і міжнародних документах Росії, Індії, Бразилії, Ірану та низки інших держав, дозволяє вважати застосування певних політичних рішень проявом експериментальної політики, яка уособлює апробацію певних теоретичних розробок у безпосередній практиці міжнародних відносин. Такий підхід втілює ідеалістично-конструктивістську методологію, за якою структуру міжнародної системи формує певний набір спільних ідей, а сфера міжнародних відносин тлумачиться як постійно конструйована та «переконструйована» мінлива реальність, що піддається цілеспрямованому впливу з метою досягнення певних бажаних результатів [1, с. 49].

В концепції зовнішньої політики Росії принцип багатополярності світу визнається центральним орієнтиром ледь не 3 початку 1990-х рр. Наголос на побудові багатополярного світу міститься у чинній версії директивних документів - Концепції зовнішньої політики РФ від 12 липня 2008 р., Стратегії національної безпеки до 2020 р. в редакціях 2009 та 2015 рр., документах БРІКС і спільних деклараціях, підписаних з окремими країнами-партнерами.

У Китаї теза про вступ світу «в період розвитку багатополярності» вперше була згадана Цзян Цземінем у квітні 1992 р. у зв’язку з розпадом СРСР. Зміст цього поняття тлумачився як перехід до структури, яка унеможливить вирішення світових справ окремими державами чи угрупованнями великих за рахунок інтересів інших. Свідоме сприяння встановленню поліцентричного устрою в міжнародній системі згадувалося в «Російсько-китайській спільній декларації про багатополярний світ та формування нового міжнародного порядку» (23 квітня 1997 р.). В офіційних коментарях багатополярний устрій визнавався більш справедливим i демократичним за однополярну чи біполярну системи, a розв'язання спірних проблем пропонувалося шляхом мирних переговорів, діалогу та консультацій «у дусі взаєморозуміння та взаємних поступок» [4, с. 86]. По мірі зміцнення китайської економіки, офіційна риторика дещо відійшла від закликів до побудови багатополярного світу та замінила антиамериканський підтекст низкою практичних вимог, включаючи перегляд умов світової валютно-фінансової системи та висунення претензій на більшу частину акваторії Південно-Китайського моря. На думку китайських експертів розподіл стратегічних ресурсів у форматі «одна наддержава - декілька провідних держав» зберігатиметься впродовж тривалого історичного періоду. 3 приводу структури міжнародної системи частіше застосовується поняття «багатосторонності», яке вказує на взаємне врахування інтересів різних країн. При цьому з 2009 р. Китай висуває претензії на бл. 80\% 
акваторії Південно-Китайського моря, що спричиняє конфлікт 3 більшістю регіональних держав, включаючи В'єтнам, Філіппіни, Малайзію, а також зі США, які претендують на роль позарегіонального арбітра.

Актуальність проблеми багатополярності та інтерес до неї суттєво зросли 3 початком кризи в українсько-російських відносинах у березні 2014 р. Застосування російським керівництвом методів системної дестабілізації проти сусідньої держави почали розглядатися як апробація «гібридної війни» та їх використання її методів як знаряддя практичної політики. Початку агресії РФ проти України передував аналіз розстановки сил у міжнародних відносинах, включаючи оцінку позицій США і ЄС у разі спроби анексії Криму. Переконавшись у неготовності Заходу активно протидіяти розширенню російського впливу в зоні «близького закордону», Москва в короткі терміни здійснила масштабну спецоперацію, що завершилася військовою окупацією та анексією Криму. Показово, що в ході цієї операції російському військовому командуванню вдалося уникнути бойових зіткнень 3 розташованими в Криму підрозділами збройних сил України.

Оприлюднена стенограма засідання РНБО від 28 лютого 2014 р., на якій розглядалися питання територіальної цілісності та загроза анексії Криму, свідчить, що гарантії безпеки України за Будапештським меморандумом 1994 р. виявилися суто декларативними. Учасники наради усвідомлювали відсутність перспективи членства України в НАТО та пов'язували російсько-грузинську війну 2008 р. 3 відмовою членів НАТО від надання Грузії та Україні «Плану дій щодо членства» на Бухарестському саміті 2008 р. За свідченням В. Наливайченка, 3 огляду на концентрацію військ РФ на кордонах України представники провідних держав Заходу наполегливо радили офіційному Києву утримуватися від будь-яких активних дій супротив, оскільки В. Путін міг скористатися приводом для початку широкомасштабного сухопутного вторгнення [6].

Отже в відносинах між Заходом і РФ зберігаються свідомі обмеження, які зумовлюють уникнення прямих зіткнень військового характеру, здатних матеріалізувати загрозу неконтрольованої ескалації. Ці обмеження формально не стосуються країн-членів НАТО, щодо яких США і Німеччина окремо підтвердили гарантії воєнної безпеки від зовнішнього нападу. За оцінками Г. Перепелиці, зміна геополітичного балансу призвела до перегляду сфер впливу у світі між новими і старими геополітичними центрами. Російська концепція багатополярності грунтується на постулатах, які заперечують однополярний світ, що «вичерпав себе» i має «згубний характер». Бажаним замінником однополярності вважається багатополярна система міжнародних відносин, у якій США не матимуть права на світове лідерство. Російське керівництво стверджує, що США і НАТО втратили здатність гарантувати безпеку Європи і надалі виступають дестабілізуючим чинником у Європі. Таким чином багатополярний світ створює для Росії шанс «переглянути результати «холодної війни» і знову повернути собі статус світової держави. ... Не маючи відповідних економічних ресурсів та політичних інструментів для досягнення своєї стратегічної мети, Росія вирішила зруйнувати існуючу систему міжнародної безпеки і міжнародного права шляхом розв'язання війни» [3, с. 11].

Пасивна реакція Заходу на анексію Криму та загрозу переростання російськоукраїнських протиріч у повномасштабну війну була сприйнята російським керівництвом як заохочення до прямого військового втручання у спровокований за 
прямою участю російської розвідки та неурядових організацій конфлікту в Донбасі. Застосування «експериментальної» тактики в Донбасі свідчило про апробацію методів «нелінійної війни», в якій Україна стала полігоном відпрацювання гібридних конфліктів, які можуть бути за потреби спровоковані в інших регіонах. Німецький історик М. Штурмер висловив думку, що «мала війна» нового типу використовується російським керівництвом для досягнення певних політичних $\mathrm{i}$ економічних результатів без ризику подолання «критичного бар'єру», який може спричинити переростання в більш масштабний збройний конфлікт. На думку М. Штурмера, в XXI ст. логіка і практика війни змінилися. Війна може тривати без початку й кінця. «Насильство залишається іiі частиною, спираючись на політичну, економічну, інформаційну технології та інші невоєнні засоби». Хоча Кремль вважає Захід своїм номінальним супротивником, російська влада не може собі дозволити війну з учасниками західних союзів. 3 огляду на це східна Україна перетворилася на локальну арену суперництва між Росією та Заходом. Але якщо російський президент В. Путин досягне успіху в Україні, це може спонукати його продовжити свій наступ без перетину «критичного порогу», який веде до прямого конфлікту з Заходом [12].

Важливий чинник новітньої багатополярності полягає в спробі використання їі адептами цивілізаційних ознак та суперечностей міжцивілізаційного характеру. Боротьба за геополітичне домінування переноситься в сферу цінностей, а цілями гібридної війни стає руйнація цивілізаційних цінностей супротивника i цілеспрямоване насадження певних установок.

Як стверджує російський теоретик багатополярності О. Дугін, ця модель відрізнятиметься від класичної Вестфальської системи тим, що «не визнає за окремою національною державою ... статус повноцінного полюсу». В структурі міжнародних відносин XXI ст. під впливом модернізації та з опорою на західні технології незахідні цивілізації «посилюють власний силовий та інтелектуальний потенціал, однак замість того, аби повністю прийняти західну систему цінностей, зберігають органічні та міцні зв'язки зі своїми традиційними культурами, релігіями і соціальними комплексами, які подекуди різко конфліктують з західними чи навіть протилежні ним. ... Замість симетричної опозиції Схід - Захід з'являється поле напружень між декількома цивілізаціями. Ці цивілізації ... в ході глобалізації та інтеграції будуть все щільніше усвідомлювати свою спільність і діяти в системі міжнародних відносин, керуючись спільними цінностями та інтересами, що випливають 3 цих цінностей» [2, с. 107]. На практиці це означає, що в межах цивілізаційних макроспільнот домінуюча держава має цілковите право втручатися в справи дрібніших країн, зберігати порядок і контролювати стан безпеки.

Оцінюючи розстановку сил та її вплив на спрямування еволюції міжнародної системи О. Дугін відзначав, що однополярність у тих чи інших формах становить модель світоустрою після 1991 р., хоча на практиці вона межує 3 номінальним збереженням Вестфальської системи та інерційними залишками двохполюсного світу. Таким чином, «американська однополярна гегемонія de facto співіснує 3 низкою міжнародних інститутів, які відтворюють баланс сил інших епох і циклів в історії міжнародних відносин. Протиріччя між станом справ de facto i de jure постійно нагадують про себе», зокрема в актах прямого втручання США чи західних коаліцій в справи суверенних держав, таких як Ірак [2, с. 25]. 
За декілька років до початку нинішньої кризи в українсько-російських відносинах К. Сівков (перший віце-президент російської Академії геополітичних проблем) писав, що в довгостроковій перспективі назрівання глобальних протиріч передбачає формування та зіткнення двох потужних коаліцій - супротивників у майбутній світовій війні. За твердженням К. Сівкова, головну лінію суперечностей формуватиме протиборство між «неоімперіалістичною коаліцією», глобальне завдання якої полягатиме в «розгромі коаліції країн, що прагнуть багатополярного світу зі встановленням над ними політичного чи навіть воєнно-політичного контролю i ліквідацією або радикальним послабленням їх державного суверенітету». Натомість мету «антиімперіалістичної коаліції» становитиме відсіч агресії неоімперіалістичної коаліції, «зрив побудови монополярного світу 3 наступним створенням багатополярного світоустрою» [5].

За вельми відвертим і ризикованим прогнозом К. Сівкова, зміст ранніх етапів конфронтації, які можуть слугувати прологом до третьої світової війни, становитимуть спроби досягнення політичних цілей невоєнними засобами та активізація локальних війн і збройних конфліктів [5]. При цьому в прогнозі відзначається, що ініціатива в створенні ідеологічних, морально-психологічних, економічних, нормативно-правових i політико-дипломатичних умов нібито належатиме західній коаліції, хоча як свідчить досвід останніх років такий інструментарій в масованому вигляді застосовує насамперед російська сторона.

Інформаційно-пропагандистські та морально-психологічні інструменти, які були використані російськими державними структурами проти України в 20142015 рр. цілком відповідають інструментам, які в вищенаведеному прогнозі віднесено до «підготовчої фази» третьої світової війни. Обгрунтовуючи свої дії російська дипломатія i пропаганда не тільки виправдовують відмову від дотримання міжнародно-правових норм їх невідповідністю російським інтересам або посиланням на їх порушення з боку держав Заходу в попередній період, але й вдаються до цілковитого перекручення фактів, покладаючи провину i відповідальність за українську кризу на США та СС.

Отже, попередня оцінка спроб встановлення багатополярної міжнародної системи дозволяє відзначити певні тенденції.

1. В структурному відношенні багатополярна система не обов'язково передбачає відносну рівність силових потенціалів основних гравців. Розбіжність у потенціалах може компенсуватися спроможністю певних держав концентрувати ресурси на пріоритетних напрямах та досягати результатів шляхом застосування силових засобів або прямих загроз використання сили.

2. Становлення багатополярності виявило слабкість нормативних та інституціональних чинників, які забезпечують регулювання міжнародної взаємодії та загальне утримання конкуренції у межах політичного діалогу та мирного співіснування.

3. Внаслідок свідомих змін у зовнішній політиці Росії спостерігається пряма небезпека переростання міждержавних суперечностей у довготривалу конфронтацію, позначену поверненням до стратегій силового стримування та активізації регіональних конфліктів як форми прямого чи опосередкованого протиборства глобальних і регіональних центрів сили.

4. Відкидаючи існуючі правила гри та заперечуючи домінування США в системі міжнародних відносин, російське керівництво нав'язує власну гегемонію 
країнам пострадянського простору та пропонує своїм партнерами в інших регіонах застосовувати аналогічні методи на основі принципу «цивілізаційної відповідальності».

5. Для України стан багатополярності, який встановлюється суто конфронтаційними методами, обіцяє довгострокову перспективу існування в епіцентрі регіонального вогнища «холодної війни». Зона напруженості безпосередньо зачіпає відносини Росії з Україною, Туреччиною та потенційно може поширитися на деякі інші країни довколишнього простору.

6. Подальший розвиток ситуації визначатиметься співвідношенням стратегій, інтересів та засобів реагування провідної четвірки міжнародних акторів, до якої входять США, СС, Китай та Росія. Загальні тенденції еволюції міжнародної системи залежать насамперед від тактики євроатлантичної спільноти в сенсі спроможності знайти форми реагування та засоби впливу, здані відновити керованість міжнародно-політичними процесами та уникнути подальших деструктивних наслідків.

\section{Література}

1. Вендт А. Четыре социологии международной политики / А. Вендт // Международные отношения: социологические подходы; под ред. П. А. Цыганкова. - М.: Гардарики, 1998. - С. 4890.

2. Дугин А. Г. Теория многополярного мира / А. Г. Дугин. - М.: Евразийское движение, 2013. -532 c.

3. Перепелиця Г. Політика Росії - це крах міжнародної безпеки: причини та наслідки / Г. Перепелиця // Матеріали міжнародної конференції «Криза сучасної системи міжнародної безпеки: причини і наслідки» (Київ, 1 липня 2015 р.). - К.: Центр дослідження Росії, 2015. - С. 1116.

4. Портяков В. Я. Видение многополярности в России и Китае и международные вызовы / В. Я. Портяков // Сравнительная политика. - 2013. - № 1 (11). - С. 86-97.

5. Сивков К. Оценка реальности мировой войны, как основного инструмента выхода из глобального кризиса, и её вероятный характер / К. Сивков. 16.11.2011. [Електронний ресурс]. Режим доступу: http://noravank.am/rus/futuris/detail.php?ELEMENT_ID=6120.

6. Стенограма засідання Ради національної безпеки і обобони України від 28 лютого 2014 року / Комітет Верховної Ради України з питань національної безпеки і оборони. 22 лютого 2016. [Електронний ресурс]. - Режим доступу: http://komnbo.rada.gov.ua/komnbo/control/uk/publish/article?art_id=53495\&cat.

7. Хантингтон С. Столкновение цивилизаций / С. Хантингтон; пер. с англ. Т. Велимеева, Ю. Новикова. - М: АСТ, 2003. - 603, [5] c.

8. Friedberg A. L. The Future of American Power / A. L. Friedberg // Political Science Quarterly. Spring 1994. - Vol. 109, no. 1. - P. 1-22.

9. Hart J. Power and Polarity in the International System / J. Hart // Sabrosky A. N. (ed.). Polarity and War. - Boulder, Col.: Westview press, 1985. - P. 25-40.

10. Kaufman S. J. The balance of power in world history / S. J. Kaufman, R. Little, W. C. Wohlforth. - New York: Palgrave Macmillan, 2007. - 296 p.

11. Kennedy P. The Rise and Fall of Great Powers. Economic Change and Military Conflict from 1500 to 2000. - New York: Random House, 1987. - 677 p.

12. Stürmer M. Die Ukraine wird nicht das letzte Kapitel sein // Die Welt, 09.03.2015. [Electronic resource]. - URL: http://www.welt.de/debatte/kommentare/article138223349/Die-Ukraine-wird-nichtdas-letzte-Kapitel-sein.html.

Надійшла до редколегії 18.07.2016 
Sergiy Tolstov, Ph.D. in History, associate professor, «The State Institution Institute of World History of NAS of Ukraine», Kyiv, Ukraine.

\section{STRUCTURAL AND POLITICAL FEATURES OF MULTIPOLARITY}

Abstract. The main trends in the forging of a multipolar international system are examined in the article. The paper focuses on the overall classification of forms of the system of international relations based on relations of material factors to evaluation of positioning of the leading countries on the international arena. The author reveales as peculiar and distinctive characteristics so some general rules of the implementation of international programs in specific political circumstances in the key periods of world history. The scientific novelty of the research comes from the comprehension of recent events and processes of political change in international relations, world politics that became intense and unexpected.

It is also demonstrated in the article that in the future a polycentric system can take different configurations, and the first evaluation reveals an increasing instability and confrontation in international relations in contemporaneous conditions of forging of the new world order. The development of international processes in that direction has been driven by Russia's aggressive and conscious actions aimed at the destruction of the previous international order established during decades of efforts. Therefore, Russia tried to revise the universally recognized rules and norms in the international community.

In conclusions, the author stresses that the structurally multipolar system of international relations does not necessarily imply a relative equality in the balance of power among the potential major players. The difference in potentials and in common opportunities can be compensated by the ability of certain states to concentrate resources in areas of key priority, and to achieve results through aggressive, unexpected use of power tools or direct threats of using force, through informational and psychological pressure.

Keywords: multipolarity, structure, civilization, balance of power, stability, confrontation.

УДК 94(73):327

Вячеслав Ціватий, кандидат історичних наук, доцент, Дипломатична академія України при МЗС України

\section{ЗОВНІШНЯ ПОЛІТИКА І ДИПЛОМАТІЯ США ХХІ СТОЛІТТЯ: ІНСТИТУЦІОНАЛЬНО-КАДРОВИЙ І РЕГІОНАЛЬНИЙ АСПЕКТИ}

Анотація. Стаття присвячена інституціонально-кадровим питанням та етапам становлення дипломатичної служби США, зокрема актуальним питанням моделі ротації дипломатів США та підвищенню їх професійної майстерності. Необхідність кардинальних змін у системі зовнішньополітичних інститутів та доцільність реформування дипломатичної служби США були усвідомлені американською політичною та академічною елітою ще в середині 1990-х років. Події 11 вересня 2001 року слугували каталізатором оновлення моделі підготовки та підвищення кваліфікації дипломатів $i$ моделі кадрового менеджменту в зовнішньополітичній сфері США та актуалізували порушену в дослідженні тему. Дипломатична служба Сполучених Штатів Америки традиційно є відносно невеликою за своєю чисельністю, але одночасно найбільш компетентною, кваліфікованою та ефективною частиною зовнішньополітичного механізму Сполучених Штатів Америки.

Саме досвід США багато в чому є иүінним і корисним для держав пострадянського простору в контексті використання практичного досвіду США, які мають усталені традииї̈ та оперативно й адекватно реагують на нові виклики і загрози глобалізованого 